\title{
Anti-Cancer Effect of Melatonin with Radioprotective/Radiosensitive Property
}

\author{
Protirakovinný účinek melatoninu s radioprotektivní \\ a radiosenzitivní vlastností
}

\author{
Cihan Y. B. \\ Department of Radiation Oncology, Kayseri Education and Research Hospital, Turkey
}

Melatonin is a hormone produced primarily in the pineal gland and secreted in the dark. In addition to the pineal gland, the endometrium, lacrimal glands, kidney, liver, bronchus, retina, adrenal glands, ovary, gastrointestinal system, placenta, testis, thymus, mast cells, natural clays and leukocyte cells also synthesize melatonin. It is involved in the regulation of physiological functions, such as regulation of the endocrine rhythm, stimulation of the immune system, antigonadotropic effects, aging, sleep and heat regulation. It also has a wide range of biological effects due to its antioxidant, anti-inflammatory and anti-tumor activity [1-5].

The anticancer effect of melatonin on tumor cells is attributed to the antioxidant, direct oncostatic and immune modulator effect. It is known that melatonin has strong antioxidant properties, both as direct and indirect radical scavenger. One of melatonin most important features is its lipophilic structure; thus, melatonin can enter all organelles, including the cell nucleus. It can also enter any tissue, including the brain. Thus, antioxidant effects can show a very wide area. Melatonin differs from classical antioxidants (vitamin $E$, vitamin $C, \beta$-carotene etc.) in various aspects. Classical antioxidants turn into prooxidants. Thus, these substances are only less harmful than the oxidant substances they reduce. However, after melatonin reacts with oxidizing agents, the intermediate products and the resulting intermediates can still be antioxidant. This property is very valuable for an antioxidant agent. To date, there is no report that melatonin has toxic properties, but it is concluded that this hormone is a very good radical scavenger [5-10]. Studies have shown that melatonin has oncostatic effects on lymphocytes, monocytes/macrophages and natural killer cells. In addition, melatonin has been reported to increase the production of IL-1, IL-6, IL-12, tumor necrosis factor from monocytes. It has also been found to increase production of IL-2, IFN- $\gamma$ and IL- 6 in cultured human peripheral blood mononuclear cells. Melatonin is also produced by a variety of cells, including monocytes and macrophages and has been shown to have an immunomodulatory effect as well as its efficacy in the protection against inflammation [1].

Studies have shown that absence of melatonin increases cancer risk and metastasis. Both animal experiments and clinical studies have shown that pinealectomy or melatonin deprivation increases the growth and metastasis of melanoma, ovary, leukemia, pituitary gland, lung, liver, and prostate cancers. High levels of melatonin have been reported to have a slowing effect on cancer growth in these tissues [1-4]. Reiter et al. reported that approximately $50 \%$ of elderly mice with low levels of melatonin developed spontaneous lymphoma, lung adenocarcinoma or sarcoma in the process. They concluded that melatonin has a positive role in increasing immune function in the elderly and may

\section{The author declares she has no potential conflicts of interest concerning drugs, pro- ducts, or services used in the study. \\ Autorka deklaruje, že v souvislosti s predmětem studie nemá žádné komerční zájmy. \\ The Editorial Board declares that the manu- script met the ICMJE recommendation for biomedical papers. \\ Redakční rada potvrzuje, že rukopis práce splnil ICMJE kritéria pro publikace zasílané do biomedicínských časopisů \\ $\exists=$ \\ Yasemin Benderli Cihan, Assoc Prof Department of Radiation Oncology Kayseri Education and Research Hospital \\ Sanayi District, Ataturk Boulevard Hastane Street, No 78 38010 Kocasinan, Kayseri, Turkey e-mail: cihany@erciyes.edu.tr \\ Submitted/Obdrženo: 24. 7. 2019 Accepted/Prijiato: 17. 9. 2019}

doi: 10.14735/amko2020150

be used as an effective treatment agent in cases of weakened immunity, such as stress, neoplastic disease or infection [4]. Again, in epidemiological studies conducted on blind people, the incidence of prostate cancer in these individuals was found to be less than that of people with vision. This is due to the higher level of melatonin in these individuals [11].

The radioprotective and radiosensitive properties of melatonin have been shown in experimental and clinical studies. How- 
ever, there is no meta-analysis and review of clinical studies in the literature. Wang et al. reported that the use of combined colorectal cancer with radiotherapy (RT) in the in vitro study showed a synergistic effect [3]. Shabeeb et al. in his study of rats showed antioxidant, antiinflammatory effects of melatonin, free radical cleaning, as well as increasing the overall survival post-irradiation, reducing the degree of DNA damage and chromosomal wear, as well as increasing the therapeutic rate of $\mathrm{RT}$, depending on the resulting skin reported to be effective in preventing damage [5]. In a study to determine the efficacy of melatonin combined therapies in 60 patients with rectal cancer, the effects of combined use of chemoradiation and melatonin on blood cell count were evaluated. They emphasized that the combined administration of chemoradiotherapy with melatonin was mild or even insignificant in the melatonin receptors of platelet, white blood cells, lymphocytes and neutrophil populations compared to chemoradiotherapy alone. These findings have shown that melatonin can play an important role in reducing the side effects of chemoradiotherapy in rectal cancer [6]. In another randomized clinical trial, adjuvant melatonin was reported to delay oral mucositis formation in patients with head and neck cancer who received concurrent chemoradiotherapy [9]. In phase II study, it has been reported that melatonin decreases radiation dermatitis due to RT in patients with breast cancer [10]. Berk et al. reported that melatonin did not have a positive effect on survival in patients who had high-dose melatonin with $\mathrm{RT}$ in cancer patients with brain metastasis. In a review of melatonin hormone-dependent cancer, prostate, breast and ovarian cancers, melatonin was shown to be effective and safe in both cancer prevention and treatment [12].

In conclusion, although melatonin is known as a hormone, it has important effects on cancer treatment due to its antioxidant and anti-inflammatory effects and anti-tumor activity. It is an advantage in the treatment of cancer, which is compatible with the immune system and has no side effects. It is obvious that the combination of melatonin with free radical scavenging molecules in patients with $\mathrm{RT}$ receiving cancer may increase the efficacy and have a positive effect on reducing the side effects. Studies on this subject are needed.

\section{References}

1. Pourhanifeh MH, Mahdavinia M, Reiter RJ et al. Potential use of melatonin in skin cancer treatment: a review of current biological evidence. J Cell Physiol 2019; 234(8): 12142-12148. doi: 10.1002/jcp.28129.

2. Vural EM, van Munster BC, de Rooij SE. Optimal dosages for melatonin supplementation therapy in older adults: a systematic review of current literature. Drugs Aging 2014; 31 (6): 441-451. doi: 10.1007/s40266-014-0178-0.
3. Wang $Q$, Sun $Z$, Du $L$ et al. Melatonin sensitizes human colorectal cancer cells to $\gamma$-ray ionizing radiation in vitro and in vivo. Int J Mol Sci 2018; 19(12): 3974. doi: 10.3390/ijms19123974.

4. Reiter RJ, Tan DX, Terron MP et al. Melatonin and its metabolites: new findings regarding their production and their radical scavenging actions. Acta Biochim Pol 2007; 54(1): 1-9.

5. Shabeeb D, Najafi M, Musa AE et al. Biochemical and histopathological evaluation of the radioprotective effects of melatonin against Gamma ray-induced skin damage in rats. Curr Radiopharm 2019; 12(1): 72-81. doi: 10.21 74/1874471012666181120163250

6. Kouhi Habibi N, Shabestani Monfared A, Ebrahimnejad Gorji K et al. The protective effects of melatonin on blood cell counts of rectal cancer patients following radio-chemotherapy: a randomized controlled trial. Clin Transl Oncol 2019; 21(6): 745-752. doi: 10.1007/s12094018-1977-2

7. Menéndez-Menéndez J, Martínez-Campa C. Melatonin: an anti-tumor agent in hormone-dependent cancers. Int J Endocrinol 2018; 2018: 3271948. doi: 10.1155/2018/3271948.

8. Farhood B, Goradel NH, Mortezaee K et al. Melatonin as an adjuvant in radiotherapy for radioprotection and radiosensitization. Clin Transl Oncol 2019; 31(3): 268-279. doi: 10.1007/s12094-018-1934-0

9. Onseng K, Johns NP, Khuayjarernpanishk T et al. Beneficial effects of adjuvant melatonin in minimizing oral mucositis complications in head and neck cancer patients receiving concurrent chemoradiation. J Altern Complement Med 2017; 23(12): 957-963. doi: 10.1089/acm.2017.0081.

10. Ben-David MA, Elkayam R, Gelernter I et al. Melatonin for prevention of breast radiation dermatitis: a phase II, prospective, double-blind randomized trial. Isr Med Assoc J 2016; 18 (3-4): 188-192.

11. Siu SW, Lau KW, Tam PC et al. Melatonin and prostate cancer cell proliferation: interplay with castration, epidermal growth factor, and androgen sensitivity. Prostate 2002; 52(2): 106-122. doi: 10.1002/pros. 10098.

12. Berk L, Berkey B, Rich T et al. Randomized phase ॥ trial of high-dose melatonin and radiation therapy for RPA class 2 patients with brain metastases (RTOG 0119). Int J Radiat Oncol Biol Phys 2007; 68(3): 852-857. doi: 10.1016/j.jijrobp.2007.01.012. 